\title{
MODEL PEMBELAJARAN GROUP INVESTIGATION UNTUK MENINGKATKAN KEMAMPUAN BERFIKIR KREATIF
}

\author{
Suprihatini \\ Titin.suprihatini65@yahoo.com \\ SMA Negeri 2 Krakatau Steel Cilegon
}

\begin{abstract}
Abstrak : Penelitian ini dilatarbelakangi oleh rendahnya kemampuan siswa untuk berfikit kreatif.Penelitian ini ditujukan untuk mengetahui efektifitas penerapan model pembelajaran Group Investigation pada pembelajaran sejarah duna meningkatkan kemampuan berfikir kreatif siswa. Metode penelitian yang digunakan kuasi eksperimen. Pengambilan data sampel menggunakan teknik nonprobability sampling.Sumber data kemampuan berfikir kreatif diperoleh dari pretest dan posttest kelas kontrol dan kelas eksperimen.Analisis data menggunakan uji t'. Hasil penelitian, terdapat pengaruh kemampuan berpikir kreatif antara siswa yang menggunakan model pembelajaran Group Investigation menggunakan model pembelajaran konvensional mengalami peningkatan lebih tinggidari padayang menggunakan model pembelajaran langsung dengan hasil analisis data dapat dilihat dari uji-t' menggunakan rumus saparated varian yaitu $-4,96>-1,33$, maka $H_{O}$ ditolak $H_{a}$ diterima. Hasil dapat dilihat dari uji-t' satu pihak dengan rumus saparated varians yaitu 0,04> $-1,33$, maka $H_{O}$ ditolak $H_{a}$ diterima.
\end{abstract}

Kata Kunci : Peningkatan Berpikir Kreatif, Model Pembelajaran Group Investigation.

\begin{abstract}
This research was motivated by the low ability of students to think creatively. This study aims to determine the effectiveness of the application of the Group Investigation learning model in learning history and to improve students' creative thinking skills. The research method used was quasi-experimental. Sampling data using nonprobability sampling techniques. Data sources of creative thinking ability were obtained from the pretest and posttest of the control class and the experimental class. Data analysis using t test'. The results of the study, there is an influence of the ability to think creatively among students who use the learning model Group Investigation using conventional learning models has increased higher than those using direct learning models with the results of data analysis can be seen from the t-test 'using the variant saparated formula viz -4,96> 1,33, then $H_{O}$ rejected $H_{a}$ be accepted. The results can be seen from one party's $t$-test with the formula saparated variants viz $0,04>-1,33$, then $H_{O}$ rejected $H_{a}$ be accepted.
\end{abstract}

Keywords: Increased Creative Thinking, Group Investigation Learning Model. 
PENDAHULUAN

Menurut Gunning dalam Aman (2011:73) secara umum tujuan pembelajaran diklasifikasikan menjadi tiga aspek yaitu mengajarkan konsep, mengajarkan ketrampilan intelektual, dan memberikan informasi kepada siswa .Pembelajaran sejarah merupakansebuah kajian ilmu yang bertujuan untuk menanamkan rasa penting untuk mempelajari tempat, waktu dan proses yang terjadi di masa lampau, saat sekaran dan masa yang akan datang. Hal ini guna memupuk kesadaran pada perserta didik bahwa mereka merupakan bagian dari sebuah bangsa, sehingga muncul rasa cinta dan bangga terhadap bangsanya. Kesanadan ini akan dimanifestasikan pada prilaku keseharian para peserta didik.

Menurut Sri Wahyuni (56:2013) pembelajaran sejarah mempunyai fungsi sebagai proses guna membangun kesadaran peserta didikakan pebubahan sosial dari masa lalu hingga saat ini. Pembangunan perspektif dan pemahaman sejaran ini agar peserta didik dapat memahami dan menjelaskan jati diri bangsa.

Berdasarkan hasil analisis pada tanggal 9 Desember 2019 bertempat di SMAN 2 Krakatau Steel Cilegon pada kelas XII IPS 1- XII IPS 6ketika pembelajaran sejarah dikelas guru tersebut menggunakan model pembelajaran satu arah yang diperankan oleh guru karena hanya menjelaskan materi, guru membuat peta konsep, kemudian mencatatnya kedalam buku catatan sehingga siswa mengalami kejenuhan ketika belajar dan kemampuan berfikir kreatifnya rendah. Terdapat berbagaipermasalahan lain yang ditemukan ketika dikelas terjadi pada saat diskusi kelompok terdapat siswa yang tidak fokus saat diskusi kelompok dan tidak mau menjalankan tugasnya, sehingga tidak dapat memahami materi yang dipelajari pada setiap kelompok dan tidak kondusif.
Wawancara dilakukan kepada guru yang mengampu mata pelajaran sejarah di SMAN 2 Krakatau Steel Cilegon guna mendapatkan gambaran pendahuluan mengenai model pembelajaran yang telah diimplementasikan.Berdasarkan observasi pada penyelenggaraan pembelajaran sejarahsetiap siswa hanya menjadi pendengar sehingga kontribusisiswa tidak terlihat secara langsung.Kesulitan yang dialami oleh guru sejarah yaitu banyak siswa yang tidak mau mendengarkan pada saat guru menyampaikan materi pembelajaran sehingga pada saat ulangan harian siswa banyak yang remedial dan pada saat remedial guru melakukan tes lisan.

Berdasarkan kondisi tersebut hasil penelitian menyatakan bahwa siswa mengalami kejenuhan pada proses pembelajaran sejarah dikelas dan belum dilatih untuk dapat mengutarakan pendapat karena pembelajaran masih terkesan berpusat kepada guru.Menurut Sanjaya (2006:259) menjelaskan bahwa pada pembelajaran konvensional siswa ditempatkan sebagai subjek yang pasif karena guru sebagai satu-satunya sumber pemberi informasi.

Terkait metode pembelajaran sejarah, perlu adanya variasi dalam mengajar sehingga siswa menjadi tertarik untuk mengikuti pembelajaran.Pembelajaran yang menarikbergantung pada implementasi model pembelajaran yang digunakan oleh guru.Pendekatan pembelajaran berpuat pada siswa menjadi model pembelajaran yang relevan diterapkan pada masa sekarang.Model pembelajaranGroup Investigationmerupakan sebuah alternative pembelajaran berpusat pada siswa.Model pembelajaran ini merupakan model pembelajaran dimana siswa lebih aktif berdiskusi guna memecahkan permasalahan sejarah yang diberikan.Siswa menjadi lebih aktif karena dengan diskusi mereka bisa saling 
bertukar pemikiran dan menemukan solusi.

Tahapan pada model pembelajaran Group Investigation yang paling utama yaitu setiap kelompok menentukan setiap tema yang akan digunakan apa saja dan harus saling bertukar pemikiran antar siswakemudian setiap siswa memiliki kemampuan berfikir kreatif.Menuntut siswa untuk lebih aktif dan terjalin interaksi dua arah.Nurulhayati dalam Rusman (2016:203) menjelaskan bahwa pembelajaran kooperatif merupakan pembelajaran yang melibatkan siswa dalam kelompok kecil dan sehingga siswa dapat saling berinteraksi antar satu dan lainnya.

Pada model ini,siswa menjadi pusat kegiatan pembelajaran dikelas, maka dari itu siswa dituntut untuk aktif dikelas,sehinggadapat meningkatkan kreatifitas siswa.Mengajak siswa berpikir dan memahami materi pelajaran sejarah, bukan hanya sekedar menjadi siswa yang pasif menerima informasi dari guru.Para siswa dapat lebih mengelaborasi kemampuan dan mengembangkan kemampuan berfikir kritis.

\section{METODE PENELITIAN}

Penelitian quantitative digunakan sebagai pendekatan penelitian ini dengan Quasy Exsperimentsebagai metode penelitian.Jenis

Quasy Exsperimentmembagi siswa kedalam dua kelompok kelas, yaitu kelas control dan kelas eksperimen Pemilihan dampel pada penelitian ini menggunakan random sampling

Metode

Experimentmenggunakan

subjek secara acak pada tiap kelas.Pada kelas eksperimen setiap subjek diberikan perlakuan, sedangkan kelompok kelas kontrol adalah kelompok yang tidak diberikan perlakuan (Sugiyono, 2014).

Teknik pengumpulan data pada penelitian ini dengan menggunakan intrumentes mengunakan lima soal yang disesuaikan dengan kemampuan berpikir kreatif. Indicator kemampuan berfikir kreatif diantaranya berfikir lancar (fluency), berpikir luwes (flexibility), berpikir orisinal(originality), danberpikir sistematis(elaboration).Terintegrasi diantaranya merumuskan hipotesis, dan mendefiniksikan operasional variabel. Uji homogenitas dan uji normalitas digunakan sebagai uji prasarat yang dilakukan pada penelitian ini sebagai teknik analisis data.

\section{PEMBAHASAN}

Penelitian yang dilakukan di kelas control diperoleh hasil tes kemampuan berpikir kreatif. Diawal pertemuan guru memberikan pretest kepada siswa dengan bentuk uraian sebanyak 5 butir soal untuk menguji kemampuan berpikir kreatif. Pada pengujian ini diperoleh data nilai siswa tertinggi80 dan didapatkan nilai terendah 10 dengan rentang 55.Diperoleh nilai rata-rata $(n=36)$ adalah sebesar 37,80 dengan simpangan baku44,9. Berikut adalah data pengujian pretest terkait berfikir kreatif pada siswa di kelas kontrol:

\section{Pretest PadaKelas Kontrol}

\begin{tabular}{ccccc}
\hline $\mathbf{N}$ & SB & $\overline{\boldsymbol{X}}$ & $\begin{array}{c}\text { Nilai } \\
\text { Tertinggi }\end{array}$ & $\begin{array}{c}\text { Nilai } \\
\text { Terendah }\end{array}$ \\
\hline 36 & 44,9 & 37,80 & 80 & 10 \\
\hline
\end{tabular}

Pada akhir pertemuan pembelajaran sejarah di kelas siswa diberikan posttest dalam bentuk uraian sebanyak 5 butir soal untuk menguji kemampuan berpikir kreatif. Pada pengujian ini nilai posttest tertinggi berada diangka 90 dan nilai terendah diangka25 dengan rentang 65.Rata-rata nilai pada kelas kontrol $(n=36)$ adalah39,91simpangan baku36,87. Berikut adalah data hasil uji posttestyang digambarkan dalam tabeldikelas kontrol:

PosttestPada Kelas Kontrol

\begin{tabular}{ccccc}
\hline $\mathbf{N}$ & SB & $\overline{\boldsymbol{X}}$ & $\begin{array}{c}\text { Nilai } \\
\text { Tertinggi }\end{array}$ & $\begin{array}{c}\text { Nilai } \\
\text { Terendah }\end{array}$ \\
\hline 36 & 36,87 & 39,91 & 90 & 25 \\
\hline
\end{tabular}




\section{Kelas Eksperimen}

Data yang diperoleh berdasarkan hasil penelitian melalui menguji siswa pada kemampuan berpikir kreatif ketika pembelajaran sejarah dikelas eksperimen. Kegiatan pertama pada pertemuan dikelas guru memberikan kepada siswa pretest dengan bentuk uraian sebanyak 5 butir soal. Pada pengujian ini diperoleh nilai tertinggi yaitu70 dan terendahdiperoleh angka15 dengan rentang 55.Rata-rata nilai hasil uji pada kelas eksperimen $(n=36)$ yaitu sebesar 39,27 dengan simpangan baku14,70. Berikut adalah hasil ujipretestyang dilakukan di kelas eksperiment:

\section{PretestPada Kelas Eksperimen}

\begin{tabular}{ccccc}
\hline $\mathbf{N}$ & SB & $\overline{\boldsymbol{X}}$ & $\begin{array}{c}\text { Nilai } \\
\text { Tertinggi }\end{array}$ & $\begin{array}{c}\text { Nilai } \\
\text { Terendah }\end{array}$ \\
\hline 36 & 14,70 & 39,27 & 70 & 15 \\
\hline
\end{tabular}

Setelah dilakukan pretest diakhir pembelajaran guru memberikan posttest dengan memberikan 5 butir soal dalam bentuk uraian.Diperoleh nilai teringgi pada pengujian ini sebesar100 dan terendah diperoleh nilai 35 dengan rentang 65.Rata-rata nilai pada kelas ekperimen $(n=36)$ yaitu sebesar 65,66 dengan simpangan baku 15,99. Berikut adalah rekapitulasi hasil pengujian posttest yang dilakukan di kelas eksperimen.

Hasil Posttest Kemampuan Berpikir Kreatif Kelas Eksperimen

\begin{tabular}{ccccc}
\hline $\mathbf{N}$ & SB & $\overline{\boldsymbol{X}}$ & $\begin{array}{c}\text { Nilai } \\
\text { Tertinggi }\end{array}$ & $\begin{array}{c}\text { Nilai } \\
\text { Terendah }\end{array}$ \\
\hline 36 & 15,99 & 65,66 & 100 & 35 \\
\hline
\end{tabular}

\section{Perbandingan Tingkat Penguasaan Berpikir Kreatif}

Telah dilakukan penelitian pada dua kelas yang dijadikan sample penelitian.Kelas eksperimen diberikan perlakuan dengan menerapkan model pembelajaran Group Investigation. Pembelajaran sejarah pada kelas control hanya diberikan pembelajaran konvensional dengan metode ceramahHasil pengujian pada kelas control menunjukan tidak ada peningkatan kemampuan berfikir kreatif siswa secara signifikan.Berdasarkan data ini menunjukan bahwa pembelajaran konvensional tidak efektif dilakukan.Lain halnya dengan implementasi di kelas eksperimen.Implementasi model pembelajaranGroup Investigationguna menunjukan peningkatan terhadap kemampuan berfikir kreatif siswa.Perbandingan hasil uji pretest dan posttest terlihat ada kenaikan secara signifikan. Data perbandingan antara pretest dan posttest tersaji pada table berikut:

\section{Diagram Perbandingan Hasil Pretest}

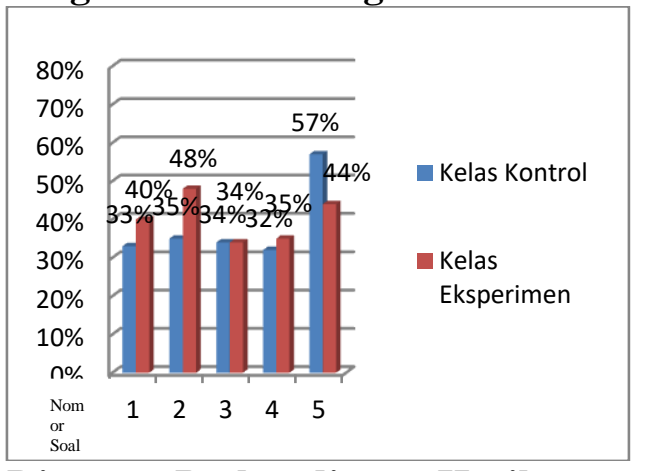

Diagram Perbandingan Hasil Posttest

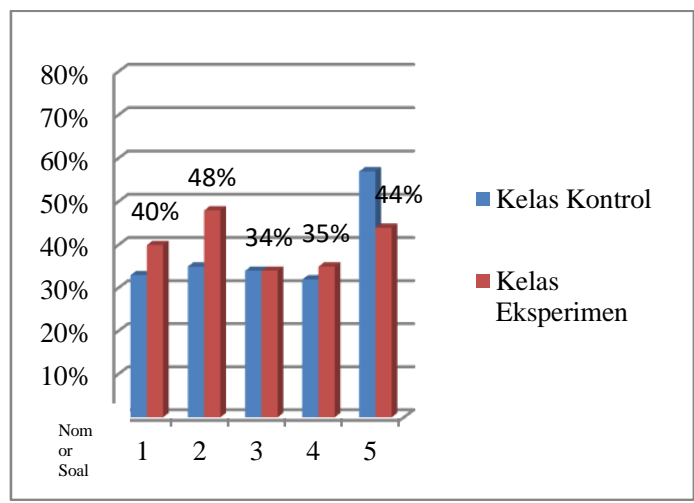

Berdasarkan diagram kemampuan berfikir kreatif diatas diperoleh presentase data hasil pengujian pretest dan posttest.Berdasarkan data diatas dapat disimpulkan bahwa siswa yang diberikan perlakuan berupa implementasi 
model pembelajaran Group Investigationcenderung mengalami peningkatan yang lebih signifikan dibandingkan dengan siswa yang diberikan metode ceramah konvensional Perbandingan dapat diamati pada presentase kemampuan berpikir kreatif dan interpretasi yang sesuai dengan kriterianya.Persentase kelas kemampuan berfikir kreatif siswa digambarkan pada table dibawah ini:

\section{Interpretasi Presentase Kemampuan} Berpikir Kreatif "Pretest"

\begin{tabular}{|c|l|c|c|}
\hline \multirow{2}{*}{ No } & \multirow{2}{*}{ Indikator } & \multicolumn{2}{|c|}{ Kelas } \\
\cline { 3 - 4 } & & Kontrol & Eksperimen \\
\cline { 3 - 4 } 1 & $\begin{array}{l}\text { Fluency } \\
\text { (Berpikir } \\
\text { lancar) }\end{array}$ & 33 & 40 \\
\hline 2 & $\begin{array}{l}\text { Flekxibility } \\
\text { (Berpikir } \\
\text { luwes) }\end{array}$ & 35 & Presentase \\
\hline 3 & $\begin{array}{l}\text { Flekxibility } \\
\text { (Berpikir } \\
\text { luwes) }\end{array}$ & 34 & 34 \\
\hline 4 & $\begin{array}{l}\text { Originality } \\
\text { (Berpikir } \\
\text { orisinal) }\end{array}$ & 32 & 35 \\
\hline 5 & $\begin{array}{l}\text { Elaboration } \\
\text { (Berpikir } \\
\text { terperinci) }\end{array}$ & 57 & 44 \\
\hline
\end{tabular}

Interpretasi Presentase Kemampuan Berpikir Kreatif "Posttest"

\begin{tabular}{|c|l|c|c|}
\hline \multirow{2}{*}{ No } & \multirow{2}{*}{ Indikator } & \multicolumn{2}{|c|}{ Kelas } \\
\cline { 3 - 4 } & & Presentase & $\begin{array}{c}\text { Eksperime } \\
\mathrm{n}\end{array}$ \\
\cline { 3 - 4 } & $\begin{array}{l}\text { Fluency } \\
\text { (Berpikir } \\
\text { lancar) }\end{array}$ & 46 & 66 \\
\hline 2 & $\begin{array}{l}\text { Flekxibility } \\
\text { (Berpikir } \\
\text { luwes) }\end{array}$ & 52 & 80 \\
\hline 3 & $\begin{array}{l}\text { Flekxibility } \\
\text { (Berpikir } \\
\text { luwes) }\end{array}$ & 47 & 59 \\
\hline 4 & $\begin{array}{l}\text { Originality } \\
\text { (Berpikir } \\
\text { orisinal) }\end{array}$ & 47 & 58 \\
\hline 5 & $\begin{array}{l}\text { Elaboratio } \\
n \text { (Berpikir } \\
\text { terperinci) }\end{array}$ & 72 & 67 \\
\hline
\end{tabular}

Berdasarkan data yang tersaji diatas, jumlah siswa yang memilikai kemampuan berfikir kreatif lebih sedikit dibandingkan jumlahsiswa pada kelas eksperimen yangmemiliki kemampuan berfikir kreatif.

\section{Uji Prasyarat}

Uji homogenitas dan normalitas dilakukan pada penelitian ini.Pada uji normalitas dengan rumuschi kuadrat $\left(\chi^{2}\right)$ pada taraf signifikan 5\%.Hasil yang didapat pada kelas kontrol diperoleh $\chi^{2}$ hitung $=-8,72$ dan nilai $\chi_{\text {tabel }}^{2}=12,59$., sedangkan pada kelas eksperimen diperoleh $\chi^{2}$ hitung $=-20,64$ dan nilai $\chi_{\text {tabel }}^{2}=12,59$.

Pada data posttest, uji normalitas dengan menggunakan rumus chi kuadrat $(\chi)$ taraf signifikan 5\%.Data kalaskontrol diperoleh $\chi^{2}{ }_{\text {hitung }}=7,54$ dan nilai $\chi_{\text {tabel }}^{2}=$ 11,070, sedangkan pada kelas eksperimen diperoleh $\chi_{\text {hitung }}^{2}=-77,32$ dan nilai $\chi_{\text {tabel }}^{2}=11,070$.

\section{Uji Homogenitas}

Berdasarkan hasil yang diperoleh dari uji normalitas kedua kelas berdistribusi normal, sehingga dilanjutkan dengan mencari homogenitas data dari kedua kelas.Uji homogenitas dimaksudkan untuk menguji apakah dua kelas penelitian tersebut memiliki variansi yang homogen.Digunakan uji $\mathrm{F}$ pada taraf signifikansi 5\% $(\alpha=0,01)$ untuk menguji homogen atau tidak data dalam penelitian. Kriteria pada pengujian homogenitas yaitu sebagai berikut: Jika $\mathrm{F}_{\text {hitung }}<\mathrm{F}_{\text {tabel}}$, maka data homogen, dan jika $\mathrm{F}_{\text {hit }}>\mathrm{F}_{\text {tabel, }}$, bisa dikatakan bahwa data tidakhomogen. Berdasarkan hasil perhitungan uji homogenitas kedua kelas memiliki variansi tidak homogen karena pada hasil pretest $\mathrm{F}_{\text {hitung }}=8,73<\mathrm{F}_{\text {tabel }}=$ 28,2 dan hasil posttest $\mathrm{F}_{\text {hitung }}=28,69$ $<\mathrm{F}_{\text {tabel }}=-28,2$. 


\section{Analisis Data}

Berdasarkan hasil uji prasarat menujukan bahwa data yang didapat berdistribusi normal dan pada uji homogenitas kedua data tersebut tidak homogen, karena memiliki variansi tidak homogen. Selanjutnya uji t' dilakukan untuk melakukan uji hipotesis dengan rumus saparated varian.Hasil pada uji prasyarat memperoleh $5 \%$ berdasarkan pengujian hipotesis.

\section{Hasil Pengujian Hipotesis Pretest}

Uji t' dilakukan pada uji hipotesis dandidapat datat hitung $=-4,96>\mathrm{t}_{\text {tabel }}=$ 1,33.Berdasarkan data uji hipotesis pada pretest menunjukan bahwa implementasi pembelajaran menggunakan model Group Investigation terbukti dapat meningkatkan kemampuan berpikir kreatif siswa.

\section{Hasil Pengujian Hipotesis Pretest}

\begin{tabular}{llc}
\hline \multicolumn{1}{c}{ Jenis Uji } & \multicolumn{1}{c}{ Stasistik } & Simpulan \\
\hline Uji-t' & $\mathrm{t}_{\text {hitung }}=$ & \\
(saparated & $-4,96$ & $H_{\alpha}$ \\
varian) & $\mathrm{t}_{\text {tabel }}=$ & Diterima \\
& $-1,33$ & \\
\hline
\end{tabular}

Pada hasiluji pengujian hipotesis posttest dengan uji $\mathrm{t}^{\mathrm{t}}$, diperoleh $\mathrm{t}_{\text {hitung }}=$ 0,04> $\mathrm{t}_{\text {tabel }}=-1,33$. Berdasarkan pengujian diatas menunjukan model pembelajaran Group Investigationdapat meningkatkan kemampuan berfikir kreatif secara signifikan, dibadingkan dengan model pembelajaran konvensional.

\section{Hasil Pengujian Hipotesis Posttest}

\begin{tabular}{lll}
\hline \multicolumn{1}{c}{ Jenis Uji } & \multicolumn{1}{c}{ Stasistik } & Simpulan \\
\hline Uji- & $\mathrm{t}_{\text {hitung }}=$ & \\
$\mathrm{t}^{\prime}($ saparated & 0,04 & $H_{\alpha}$ \\
\cline { 2 - 2 } varian) & $\mathrm{t}_{\text {tabel }}=$ & Diterima \\
& $-1,33$ & \\
\hline
\end{tabular}

\section{KESIMPULAN}

Bedasarkan data hasil uji coba dan test pada penelitian ini, disimpulkan bahwa implementasi Group Investigation dapat meningkatkan kemampuan berfikir kreatif serta efektif ketika dilakukan di kelas, sedangkan penggunaan model pembelajaran konvesional tidak terbukti efektif untuk meningkatkan daya berfikir kreatif pada siswa. Kesimpulan tersebut didasarkan pada perbandingan nilai ratarata siswa pada posttestsebesar 39,91di kelas control dan 65,66 pada kelas eksperimen.

Berdasarkan datauji hipotesis dengan uji t' satu pihak menggunakan rumus saparated varians, terdapat penerimaan yang menunjukkan hasil $H \alpha$ diterima dan $\mathrm{Ho}$ ditolak. Perolehan $\mathrm{t}_{\text {hitung }}=$ 0,04dan $t_{\text {tabel }}=-1,33$ dengan $\alpha=0,05$ kemudian diperoleh $t_{\text {hitung }}>t_{\text {tabel }}$ atau 0,04 $>-1,33$. 


\section{DAFTAR PUSTAKA}

Agung Leo dan Sri Wahyuni. 2013. Perencanaan Pembelajaran Sejarah. Yogyakarta: Penerbit Ombak.

Aman. 2011. Model Evaluasi

Pembelajaran Sejarah.

Yogyakarta: Penerbit

Ombak.Cholid Narudin dan Abu

Achmadi. 2009. Metode

Penelitian. Jakarta: PT. Bumi

Aksara .

Rusman. 2016. Model-model

Pembelajaran: Mengembangkan

Profesionalisme Guru. Jakarta:

Rajawali Pers.

Sanjaya, Wina. 2006. Strategi

Pembelajaran: Berorientasi

Standar Proses Pendidikan.

Jakarta: Kencana Prenada Media

Group.

Shoimin, Aris. 2014. 68 Model

Pembelajaran Inovatif dalam

Kurikulum 2013. Yogyakarta:

Ar-ruzz Media.

Sugiyono. 2014. Metode Penelitian

Kuantitatif, Kualitatif, dan $R \& D$.

Bandung : Alfabeta.

Suprijono, Agus. 2015. Cooperative Learning: Teori dan Aplikasi PAIKEM. Yogyakarta : Pustaka Pelajar Offset. 